\title{
Pengaruh Metode Talking Stick Terhadap Keterampilan Berbicara Siswa Dalam Pembelajaran Bahasa Arab Kelas Viii Mts. Al-Amien Putri 1
}

\section{Zamilatul Fitriyah, Luthfatul Qibtiyah}

\author{
Institut Dirosat Islamiyah Al-Amien Prenduan (IDIA)
}

email: zamilatulfitriyah@gmail.com, lutfatulqibtiyah@gmail.com

\section{Article History:}

Received: February 13, 2021

Revised: March 15, 2021

Accepted: March 22, 2021

Published: March 23, 2021

https://doi.org/10.36835/ al-irfan.v4i1.4346

Keywords:

Talking Stick Method, speaking skills, learning Arabic
Abstract: Speaking skills are very important in learning Arabic. However, until now many students have difficulty speaking with Arabic language, because speaking skills must be based on confidence to be able to express and speak correctly and well. The purpose of this study was to determine whether there is an influence and how much influence the Talking Stick Method on students' speaking skills in learning Arabic. This study uses a quantitative approach. The research was conducted in class VIII A MTs. Al-Amien Putri 1 with a population of 34 students. Data collection techniques used in this study, there are three methods, namely questionnaires, observation and documentation. The data analysis technique in this study is a simple linear regression test with the help of a Statistical Package For Social Science (SPSS) For Windows versi 16.0. Based on the research results indicate that $F$ count $=7,548$ with a significance level of $0,010<0,05$, it can be seen that there is a significant influence between the Talking Stick method variable $(X)$ on the speaking skill variable $(Y)$.

Abstrak: Keterampilan berbicara sangat penting dalam pembelajaran bahasa Arab, karena keterampilan berbicara merupakan suatu aplikasi dalam bahasa Arab dan merupakan tujuan awal seseorang untuk bisa mendalami suatu bahasa. Keterampilan berbicara harus didasari dengan percaya diri untuk dapat mengungkapkan dan berbicara secara benar dan baik. Tujuan penelitian ini adalah untuk mengetahui apakah ada pengaruh serta seberapa besar pengaruh Metode Talking Stick terhadap keterampilan berbicara siswa dalam pembelajaran bahasa Arab. Dalam penelitian ini peneliti menggunakan pendekatan kuantitatif, Penelitian dilaksanakan di kelas VIII A MTs. Al-Amien Putri 1 dengan jumlah populasi 34 siswa. Teknik pengumpulan data yang digunakan dalam penelitian ini, ada tiga metode yaitu angket, observasi dan dokumentasi. Teknik analisis data dalam penelitian ini berupa uji regresi linier sederhana dengan bantuan Statistical Package For Social Science (SPSS) For Windows versi 16.0. Berdasarkan hasil penelitian menunjukkan bahwa $F$ hitung $=7,548$ dengan tingkat signifikansi sebesar 0,010 $<0,05$, maka dapat diketahui bahwa ada pengaruh variabel metode Talking Stick $(X)$ terhadap variabel keterampilan berbicara $(\mathrm{Y})$. 


\section{Pendahuluan}

Pembelajaran merupakan kegiatan belajar mengajar yang dilakukan secara maksimal oleh seorang guru agar anak didik dapat melakukan kegiatan belajar dengan baik. Dengan kata lain pembelajaran adalah upaya yang dilakukan oleh guru dalam menciptakan kegiatan belajar materi tertentu yang kondusif untuk mencapai tujuan. ${ }^{1}$

Sementara bahasa Arab merupakan salah satu bahasa dunia yang telah mengalami perkembangan social masyarakat dan ilmu pengetahuan. Bahasa Arab dalam kajian sejarah termasuk rumpun bahasa semit yaitu rumpun bahasa yang dipakai bangsa-bangsa yang tinggal di sekitar sungai Tigris dan Furat, dataran Syiria dan jazirah Arabia (Timur Tengah). Pembelajaran bahasa dapat membantu siswa untuk mengenal dirinya, dan dengan bahasa seseorang dapat berkomunikasi dan berinteraksi dengan sesama. Menurut Fajriah belajar bahasa sangat penting bagi anak usia dini. ${ }^{2}$ Karena mempelajari bahasa Arab membutuhkan waktu yang relatif lama karena bahasa Arab bukanlah bahasa yang biasa kita gunakan dalam sehari-hari.

Bahasa Arab termasuk salah satu bahasa dunia yang memiliki kedudukan tinggi sebagai bahasa internasional. Dipilihnya bahasa Arab sebagai mata pelajaran di lembaga-lembaga pendidikan Islam karena bahasa merupakan bahasa al-Qur'an yang merupakan sarana komunikasi kalamullah. Firman Allah swt dalam Q.S Yusuf ayat 1-2:

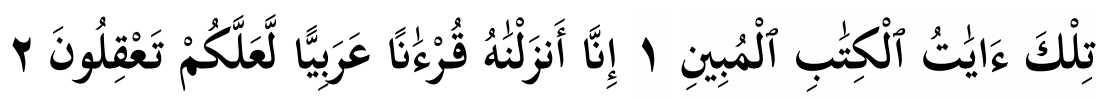

“Itulah ayat-ayat al-Qur'an yang jelas. Sesungguhnya, kami telah menurunkan al-Qur'an itu dalam bahasa Arab agar kamu memahaminya".

Ayat di atas menjelaskan pentingnya mempelajari bahasa Arab, bukan saja karena menjadi faktor komunikasi berbahasa, tetapi juga karena bahasa menjadi alat memahami al-Qur'an. Pembelajaran bahasa Arab diajarkan secara terprogram, memiliki kurikulum, metode dan media dan bahasa Arab juga diajarkan diajarkan di sekolah umum hingga perguruan tinggi. ${ }^{3}$

32.

1 Acep Hermawan, Metodologi Pembelajaran Bahasa Arab (Bandung: PT Remaja Rosdakarya, 2011),

2 Zahrotun Fajriah, "Peningkatan Penguasaan Kosakata Bahasa Arab Melalui Penggunaan Media Kartu Kata Bergambar," Jurnal Pendidikan Usia Dini 09, no. 1 (2015): 108.

${ }^{3}$ Marni and M. Yusuf. T, "Penggunaan Metode Talking Stick Untuk Meningkatkan Mahârat AlKalâm Dalam Mata Pelajaran Bahasa Arab," Auladuna 2, no. 1 (2015): 88. 
Dalam pembelajaran bahasa Arab terdapat empat ketampilan berbahasa yaitu keterampilan mendengar (maharah al-istima'), keterampilan berbicara (maharah al-kalam), keterampilan menulis (maharah al-kitabah) dan keterampilan membaca (maharah alqiro'ah). ${ }^{4}$ Salah satu yang harus dipelajari oleh siswa yaitu keterampilan berbicara. Keterampilan berbicara sangat penting dalam pembelajaran bahasa Arab, karena keterampilan berbicara merupakan suatu aplikasi dalam bahasa Arab dan merupakan tujuan awal seseorang untuk bisa mendalami suatu bahasa. ${ }^{5}$

Keterampilan berbicara berasal dari kata terampil yang berarti mampu dan cekatan. Keterampilan sendiri memiliki arti kecakapan untuk menyelesaikan tugas. Sedangkan berbicara adalah kemampuan mengungkapkan bunyi-bunyi artikulasi atau kata-kata untuk mengekspresikan, menyatakan serta menyampaikan pikiran, gagasan dan perasaan. ${ }^{6}$ Jadi keterampilan berbicara adalah suatu keterampilan untuk menyampaikan pesan secara lisan kepada orang lain dengan menggunakan kaidah nahwu-shorrof agar apa yang disampaikan dapat dengan mudah dimengerti oleh lawan bicaranya. Dan keterampilan berbicara bahasa Arab dapat dipelajari dan dilatih secara terus menerus dengan adanya rasa semangat dan keinginan belajar dari seseorang untuk mengikuti proses pembelajaran bahasa Arab. Dan keterampilan berbicara juga harus didasari dengan percaya diri untuk dapat mengungkapkan secara benar dan baik. $^{7}$

Mts Al-Amien 1 Prenduan adalah lembaga yang berada di bawah naungan Pondok Pesantren Putri 1 Al-Amien. Dalam pembelajaran bahas Arab di Mts Al-Amien Putri 1 seringkali terdapat beberapa masalah, seperti siswa merasa kesulitan dalam memahami materi dan menguasai kosa kata bahasa Arab. Dan siswa kurang mampu mempraktikkan keterampilan berbicara bahasa Arab dengan baik.

Sebagaimana diketahui bahwa metode memiliki peran yang sangat penting dalam proses belajar megajar sehingga pembelajaran dapat berjalan dengan baik dan sistematis. Bahkan dapat dikatakan proses pembelajaran tidak dapat berlangsung tanpa adanya metode. Metode secara bahasa berarti cara. Sedangkan secara umum, metode

4 Syaiful Mustofa, Strategi Pembelajaran Bahasa Arab Inovatif (Malang: UIN Maliki Press, 2017), 2.

5 Taufik Taufik, Pembelajaran Bahasa Arab MI (Surabaya: UIN Sunan Ampel Press, 2016), 47.

${ }^{6}$ Dkk. Nawawi, Keterampilan Berbicara Sebagai Suatu Keterampilan Berbahasa (Jakarta: Uhamka Press, 2017), 22.

${ }^{7}$ Mustofa, Strategi Pembelajaran Bahasa Arab Inovatif, 136. 
diartikan sebagai suatu cara yang dipakai untuk mencapai tujuan tertentu. ${ }^{8}$ Adapun faktor-faktor dalam menentukan metode pembelajaran antara lain tujuan pemebelajaran, kemampuan guru, kemampuan peserta didik, jumlah peserta didikjenis materi, waktu dan fasilitas yang ada. Tujuan pembelajaran merupakan kriteria penting dalam menentukan metode pembelajaran, karena metode merupakan cara menyajikan isi pembelajaran untuk mencapai tujuan pembelajaran.

Untuk meminimalisir masalah yang terjadi, guru bahasa Arab di Mts. Al-Amien Putri 1 memilih metode baru bagaimana siswa akan bangkit kembali dalam belajar bahasa Arab dan bisa memahami materi yang diajarkan dan dapat mempraktikkannya dalam keterampilan berbicara bahasa Arab. Guru bahasa Arab memilih menggunakan metode permainan untuk mengatasi kebosanan siswa dalam belajar agar suasana kelas menjadi menyenangkan dan tidak monoton. Salah satunya adalah dengan menggunakan metode Talking Stick.

Metode Talking stick merupakan salah satu model pembelajaran kooperatif. Kelough dalam Efendy mendefinisikan cooperative learning sebagai suatu macam strategi pembelajaran secara berkelompok, siswa belajar bersama dan saling membantu dalam membuat tugas dengan penekanan pada saling support di antara anggota. Siswa yang belajar dalam kelompok akan belajar lebih banyak dibandingkan dengan siswa yang belajar dalam sistem klasikal. ${ }^{9}$ Sedangkan menurut Suprijono, model pembelajaran talking stick adalah model pembelajaran yang memberikan kesempatan kepada peserta didik untuk dapat bekerja sama dalam mempelajari materi pemebelajaran dengan siswa lain, dengan demikian siswa akan lebih aktif dalam kegiatan pembelajaran. Pembelajaran dengan model talking stick dapat mendorong peserta didik untuk berani dalam mengemukakan pendapat. ${ }^{10}$

Pembelajaran bahasa Arab dengan metode Talking stick diawali dengan penjelasan guru mengenai materi pokok yang akan dipelajari. Siswa diberi kesempatan membaca dan mempelajari materi tersebut. Selanjutnya guru meminta siswa untuk menutup bukunya. Guru mengambil tongkat yang telah dipersiapkan sebelumnya, dan tongkat tersebut diberikan kepada salah satu siswa. Siswa yang menerima tongkat 2014), 45 .

8 Syifa S. Mukrima, 53 Metode Belajar Dan Pembelajaran Plus Aplikasinya (Bandung: Bumi Siliwangi,

${ }^{9}$ Ahmad Fuad Efendy, Metodologi Pengajaran Bahasa Arab (Malang: Misykat, 2009), 195. 109.

10 Agus Suprijono, Cooperative Learning Dan Aplikasi PAIKEM (Yogyakarta: Pustaka Belajar, 2009), 
tersebut diharuskan berbicara dengan menggunakan bahasa Arab. Demikian seterusnya, ketika tongkat itu bergulir ke siswa yang lain. Dengan metode Talking stick akan melatih siswa untuk berani berbicara dengan menggunakan bahasa Arab.

Hal tersebut ditegaskan oleh Fathurrohman dalam penelitiannya bahwa penerapan model Talking Stick berbantuan media gambar dalam pembelajaran bahasa Indonesia pada siswa kelas III SD Islam Tarbiyatul Athfal Surabaya dapat meningkatkan aktivitas dan hasil keterampilan berbicara siswa. ${ }^{11}$ Rahmi, dkk juga menyatakan bahwa dengan adanya penerapan model pembelajaran kooperatif tipe Talking Stick pada siswa kelas VB SDIT Insan Utama Negeri Pekanbaru menyebabkan aktivitas siswa semakin meningkat. Karena siswa sudah terbiasa dan telah memahami langkah-langkah penerapan model pembelajaran kooperatif tipe Talking Stick, sehingga siswa lebih memahami materi yang sedang dipelajari. Aktivitas guru dan siswa sangat berperan untuk ketuntasan siswa baik secara individu maupun klasikal. ${ }^{12}$

Penelitian ini bertujuan untuk mengetahui adakah pengaruh Metode Talking Stick terhadap keterampilan berbicara siswa dalam pembelajaran bahasa Arab Kelas VIII MTs Al-Amien Putri 1.

\section{Isi}

\section{Metode Penelitian}

Dalam penelitian ini, peneliti menggunakan pendekatan kuantitatif, dengan variabel bebas $(\mathrm{X})$, yaitu tentang Metode Talking Stick dan variabel terikat $(\mathrm{Y})$ tentang Keterampilan berbicara siswa. Metode kuantitatif adalah penelitian yang berkaitan dengan kegiatan ilmiah yang dilakukan seorang peneliti dalam memutuskan apa yang akan diteliti, merumuskan masalah yang spesifik, mengumpulkan data melalui angkaangka dari partisipan dan menganalisis angka-angka tersebut dengan menggunakan statistik. ${ }^{13}$ Penelitian ini ingin mengetahui adanya Pengaruh Metode Talking Stick Terhadap Keterampilan Berbicara Siswa dalam pembelajaran bahasa arab di MTs. AlAmien Putri 1.

${ }^{11}$ Fathurrohman, "Model Talking Stick Dan Kemampuan Berbicara," Scholastica: Jurnal Pendidikan dan Kebudayaan 1, no. November (2019): 224.

12 Alfi et al Rahmi, "Penerapan Model Pembelajaran Kooperatif Tipe Talking Stick Dapat Meningkatkan Hasil Belajar IPS Siswa Kelas VB SDIT Insan Utama Pekanbaru," Jurnal Tunjuk AJar 1 (2018): 101.

13 Agustinus Bandur, Penelitian Kualitatif: Metodologi, Desain Dan Teknik Analisis Data Dengan NVIVO 11 Plus (Jakarta: Mitra Wacana Media, 2016), 26. 
Penelitian ini dilaksanakan di kelas VIII A MTs. Al-Amien Putri 1 dengan populasi 34 siswa. Adapun teknik pengumpulan data yang digunakan dalam penelitian ini, ada tiga metode yaitu angket, observasi dan dokumentasi. Metode angket ini digunakan sebagai metode pokok untuk mendapatkan informasi dari responden tentang pengaruh metode Talking Stick terhadap keterampilan berbicara siswa dalam pembelajaran bahasa Arab. Sedangkan metode observasi digunakan untuk mengumpulkan data dengan melakukan pengamatan secara langsung ke objek penelitian untuk melihat suatu kegiatan pembelajaran tersebut. Dan metode dokumentasi dilakukan untuk mencari data mengenai variabel yang berupa catatan, transkrip, foto kegiatan pembelajaran dan sebagainya.

Analisis data adalah proses pengelompokan, mentabulasi, menyajikan, dan melakukan perhitungan data untuk menguji hipotesis yang diterapkan. ${ }^{14}$ Teknik analisis data dalam penelitian ini terdiri dari tiga bentuk analisa yaitu, pertama, uji validitas, untuk menguji validitas digunakan teknik korelasi produk moment dari pearson dengan bantuan SPSS For Windows. Kedua, uji reabilitas, dalam hal ini diukur dengan metode konsistensi internal dengan teknik Alpha dengan bantuan Statistical Package For Social Science (SPSS) For Windows Versi 24.0. Ketiga, uji instrument, adapun metode yang digunakan dalam menganalisa data adalah uji regresi linier sederhana dengan bantuan Statistical Package For Social Science (SPSS) For Windows.

\section{Uji Validitas dan Reliabilitas Instrumen}

Sebelum melakukan pengujian hipotesis, perlu dilakukan uji validitas dan reliabilitas intrumen. Adapun hasil uji validitas dengan menggunakan digunakan tabel korelasi produk moment dari Pearson dengan bantuan Statictical Package For Social Science (SPSS) For Windows Versi 16.0, adalah sebagaimana berikut:

1. Variabel X (Metode Talking Stick)

Item kuesoner dikatakan valid jika nilai $\mathrm{r}$ hitung lebih besar dari nilai $\mathrm{r}$ table. Adapun $r$ table dapat dilihat pada table $r$ tabel, dimana nilai taraf kepercayaan (sig 5\%) adalah $=0.374$, jika nilai item lebih kecil dari 0.374 maka item tersebut tidak valid dan

${ }_{14}$ Mohammad \& Hisyam El Qadirie Rusli, Metode Penelitian Kuantitatif Dan Kualitatif (Sumenep: LP3M Pramadani, 2013), 9. 
dibuang untuk hasil penelitian yang lebih baik. Adapun hasil uji validitas angket adalah sebagaimana berikut:

Hasil Uji Validitas Angket Variabel X

(Metode Talking Stick)

\begin{tabular}{|c|c|c|c|}
\hline $\begin{array}{c}\text { NO } \\
\text { ITEM }\end{array}$ & HASIL $\mathrm{r}_{\text {kerja }}$ & $\begin{array}{c}\mathrm{T}_{\text {tabel }} \text { SIGNIFIKANSI } \\
5 \%\end{array}$ & KET \\
\hline 1 & 0.599 & 0.374 & VALID \\
\hline 2 & 0.256 & 0.374 & TIDAK VALID \\
\hline 3 & 0.617 & 0.374 & VALID \\
\hline 4 & 0.632 & 0.374 & VALID \\
\hline 5 & 0.796 & 0.374 & VALID \\
\hline 6 & 0.628 & 0.374 & VALID \\
\hline 7 & 0.038 & 0.374 & TIDAK VALID \\
\hline 8 & 0.796 & 0.374 & VALID \\
\hline 9 & 0.776 & 0.374 & VALID \\
\hline 10 & 0.470 & 0.374 & VALID \\
\hline 11 & 0.223 & 0.374 & TIDAK VALID \\
\hline 12 & 0.796 & 0.374 & VALID \\
\hline 13 & 0.530 & 0.374 & VALID \\
\hline 14 & 0.599 & 0.374 & VALID \\
\hline
\end{tabular}

Dari hasil uji validitas, butir-butir soal yang tidak valid ada 3 item dan tidak peneliti uji reliabilitasnya. Sedangkan butir-butir soal yang valid ada 11 item, kemudian dianalisis reliabilitasnya, dengan hasil sebagaimana berikut:

Case Processing Summary
\begin{tabular}{|rl|r|r|}
\hline & & N & \multicolumn{1}{c|}{$\%$} \\
\hline Cases & Valid & 28 & 100.0 \\
& Excluded & & \\
& Total & & .0 \\
& 28 & 100.0 \\
\hline
\end{tabular}

a. Listwise deletion based on all variables in the procedure. 


\section{Reliability Statistics}

\begin{tabular}{|r|r|}
\hline $\begin{array}{c}\text { Cronbach's } \\
\text { Alpha }\end{array}$ & N of Items \\
\hline .792 & 11 \\
\hline
\end{tabular}

Dari hasil analisis di dapat nilai Alpha sebesar 0.792, sedangkan nilai r kritis (uji 2 sisi) pada signifikansi $5 \%$ adalah sebesar $=0,374$, maka dapat disimpulkan bahwa butir-butir instrument penelitian ini reliable.

\section{Variabel Y (Keterampilan Berbicara)}

Sebagaimana pada table $X$, Item kuesioner pada tableY ini dikatakan valid jika nilai $r$ hitung lebih besar dari nilai $r$ table. Adapun $r$ table dengan nilai taraf kepercayaan $(\operatorname{sig} 5 \%)$ adalah $=0.374$, jika nilai item lebih kecil dari 0.374 maka item tersebut tidak valid dan dibuang untuk hasil penelitian yang lebih baik. Adapun hasil uji validitas angket pada table $Y$ ini adalah sebagaimana berikut:

Hasil Uji Validitas Angket Variabel Y

(Keterampilan Berbicara)

\begin{tabular}{|c|c|c|c|}
\hline $\begin{array}{c}\text { NO } \\
\text { ITEM }\end{array}$ & HASIL $\mathrm{r}_{\text {kerja }}$ & $\begin{array}{c}\mathrm{T}_{\text {tabel }} \text { SIGNIFIKANSI } \\
5 \%\end{array}$ & KET \\
\hline 1 & 0.847 & 0.374 & VALID \\
\hline 2 & 0.471 & 0.374 & VALID \\
\hline 3 & 0.567 & 0.374 & VALID \\
\hline 4 & 0.367 & 0.374 & TIDAK VALID \\
\hline 5 & 0.554 & 0.374 & VALID \\
\hline
\end{tabular}

Berdasarkan table di atas dapat disimpulkan bahwa dari 5 item instrument yang dinyatakan valid ada 4 item, dan item soal yang tidak valid ada 1 item.

Kemudian sebagaimana diatas, dari hasil uji validitas, butir-butir soal yang valid kemudian dianalisis reliabilitasnya, dengan hasil sebagaimana berikut: 


\section{Case Processing Summary}

\begin{tabular}{|rl|r|r|}
\hline & & $\mathrm{N}$ & \multicolumn{1}{|c|}{$\%$} \\
\hline Cases & Valid & 28 & 100.0 \\
& Excluded & 0 & .0 \\
& Total & 28 & 100.0 \\
\hline
\end{tabular}

a. Listwise deletion based on all variables in the procedure.

\section{Reliability Statistics}

\begin{tabular}{|r|r|}
\hline $\begin{array}{c}\text { Cronbach's } \\
\text { Alpha }\end{array}$ & N of Items \\
\hline .553 & 4 \\
\hline
\end{tabular}

Dari hasil analisis pada variabel Y didapatkan nilai Alpha sebesar 0.553, sedangkan nilai $\mathrm{r}$ kritis (uji 2 sisi) pada signifikansi 5\% adalah sebesar $=0,374$ maka dapat disimpulkan bahwa butir-butir instrument penelitian pada variabel $\mathrm{Y}$ ini juga reliable.

\section{Analisis Intrumen}

Sebelumnya telah peneliti paparkan data penelitian yang telah peneliti peroleh dari responden yang terdiri dari 34 siswa. Namun data tersebut belum dapat menguji hipotesis yang diajukan pada tujuan penulisan jurnal tentang pengaruh metode talking stick untuk meningkatkan keterampilan berbicara siswa dalam pembelajaran bahasa Arab kelas VIII MTs Al-Amien Putri 1.

Maka untuk menguji hipotesis tersebut, data yang telah peneliti sajikan sebelumnya perlu pengolahan dan analisa lebih lanjut. Peneliti melakukan analisis hasil penelitian secara kuantitatif Untuk mengetahui ada tidaknya pengaruh metode talking stick untuk meningkatkan keterampilan berbicara siswa dalam pembelajaran bahasa Arab kelas VIII MTs Al-Amien Putri 1, maka peneliti menggunakan teknik analisa statistik regresi linier sederhana dengan rumus:

$$
\mathrm{Y}=\mathrm{a}+\mathrm{bX}
$$


Keterangan :

$\mathrm{Y}=$ Variabel terikat yang diproyeksikan

$\mathrm{X} \quad=$ Variabel bebas

A $\quad=$ Nilai konstanta

B = Nilai arah sebagai penentu prediksi

Dan untuk menghitung data statistik dalam penelitian ini peneliti menggunakan aplikasi SPSS versi 16.0 dan hasil adalahsebagai berikut:

Sebelum mengetahui hasilnya terlebih dahulu peneliti akan mencantumkan nilai normalitas dari data stategi pembelajaran partisipan dan hasil belajar mata pelajaran bahasa Arab dalam keterampilan berbicara.

Model Summary

\begin{tabular}{|l|r|r|r|r|}
\hline Model & \multicolumn{1}{|c|}{$\mathrm{R}$} & R Square & $\begin{array}{c}\text { Adjusted R } \\
\text { Square }\end{array}$ & $\begin{array}{c}\text { Std. Error of } \\
\text { the Estimate }\end{array}$ \\
\hline 1 & $.437 \mathrm{a}$ & .191 & .166 & .497 \\
\hline
\end{tabular}

a. Predictors: (Constant), METODE TALKING STICK

Dari tabel model summary ini, diperoleh informasi tentang besarnya pengaruh dari variable independen (Metode Talking Stick) terhadap variabel dependen (Keterampilan Berbicara). Pengaruh tersebut disimbolkan dengan R (korelasi). Seperti yang terlihat dalam tabel model summary diatas nilai pada kolom $R$ adalah 0,437 artinya pengaruh variable independen (Metode Talking Stick) terhadap variable dependen (Keterampilan Berbicara) adalah 437\%, Namun nilai tersebut bisa dikatakan "terkontaminasi" oleh berbagai nilai pengganggu yang mungkin menyebabkan kesalahan pengukuran, untuk itu SPSS memberikan alternative nilai R Square sebagai perbandingan akurasi pengaruhnya. Terlihat bahwa nilai R Square sebesar 0,191 yang artinya 19,1\%. Kolom selanjutnya pada tabel Model Summary memperlihatkan tingkat keakuratan model regresi dapat dilihat pada kolom Standard Error of The Estimate, di situ tertera angka 497. 
ANOVA $^{b}$

\begin{tabular}{|c|c|c|c|c|c|c|}
\hline \multicolumn{2}{|c|}{ Model } & $\begin{array}{l}\text { Sum of } \\
\text { Squares }\end{array}$ & df & Mean Square & $\mathrm{F}$ & Sig. \\
\hline \multirow[t]{3}{*}{1} & Regression & 1.864 & 1 & \multirow{3}{*}{$\begin{array}{r}1.864 \\
.247\end{array}$} & \multirow[t]{3}{*}{7.548} & \multirow[t]{3}{*}{.010} \\
\hline & Residual & 7.901 & 32 & & & \\
\hline & Total & 9.765 & 33 & & & \\
\hline
\end{tabular}

a. Predictors: (Constant), METODE TALKING STICK

b. Dependent Variable: KETERAMPILAN BERBICARA

Tabel Anova menjelaskan tentang apakah ada pengaruh tidaknya variabel independen (Metode Talking Stick) terhadap variabel dependen (Keterampilan Berbicara). Untuk mengambil keputusan tersebut dapat digunakan dua cara, pertama lihat nilai Sig. (Signifikansi). Pada tabel anova nilai sig. tertera sebesar 0,010 maka dapat disimpulkan bahwa metode talking stick berpengaruh terhadap keterampilan berbicara siswa. Hal ini dengan mengikuti taraf sig. 0,05 sebagai nilai cut off dari nilai signifikansi. Artinya jika nilai probabilitas (signifikansi) dibawah 0,05 maka variabel independen berpengaruh terhadap variabeldependen. Cara keduadengan membandingkan FHitung dan F-Tabel, dimana nilai F yang dihasilkan dalam tabel Anova yaitu sebesar 7.548 Setelah menemukan F-Hitung lalu dibandingkan dengan F-Tabel sebesar 0,339

\section{Coefficients ${ }^{a}$}

\begin{tabular}{|c|c|c|c|c|c|c|}
\hline \multirow{2}{*}{\multicolumn{2}{|c|}{ Model }} & \multicolumn{2}{|c|}{$\begin{array}{l}\text { Unstandardized } \\
\text { Coefficients }\end{array}$} & \multirow{2}{*}{$\begin{array}{c}\begin{array}{c}\text { Standardized } \\
\text { Coefficients }\end{array} \\
\text { Beta }\end{array}$} & \multirow[b]{2}{*}{$\mathrm{T}$} & \multirow[b]{2}{*}{ Sig. } \\
\hline & & B & Std. Error & & & \\
\hline 1 & (Constant) & 4.925 & 2.084 & & 2.363 & .024 \\
\hline & $\begin{array}{l}\text { METODE TALKING } \\
\text { STICK }\end{array}$ & .202 & .073 & .437 & 2.747 & .010 \\
\hline
\end{tabular}

a. Dependent Variable: KETERAMPILAN BERBICARA

Tabel ini digunakan untuk melihat pengaruh variabel. Caranya ada dua, pertama, dengan cara melihat nilai sig yaitu 0,010 lebih kecil dari 0,05, maka kesimpilannya bahwa metode talking stick berpengaruh terhadap keterampilan berbicara siswa. Kedua, dengan cara membandingkan nilai t-hitung yaitu nilai pada kolom $\mathrm{t}$ yang dihasilkan SPSS pada tabel coefficient 2.747 dengan t-tabel yaitu 2.039. 
Maka apabila nilai $\mathrm{t}$ tabel lebih kecil dari nilai $\mathrm{t}$ hitung maka kesimpulannya ada pengaruh metode talking stick untuk meningkatkan keterampilan berbicara siswa dalam pembelajaran bahasa Arab kelas VIII MTs Al-Amien Putri 1.

\section{Respon Siswa Kelas VIII A MTs Al-Amien Putri 1 terhadap Penggunaan Metode Talking Stick untuk Meningkatkan Keterampilan Berbicara}

Berdasarkan hasil penelitian yang dilakukan di MTs Al-Amien Putri 1 menunjukkan bahwa dari hasil angket variabel X (Metode Talking Stick) respon siswa sebanyak 14 butir pernyataan kepada 34 siswa kelas VIII MTs menunjukkan bahwa terdapat 3 butir soal yang tidak valid, sedangkan hasil angket variabel Y (Keterampilan Berbicara) terdapat 1 butir soal yang tidak valid. Sehingga tidak peneliti uji reliabilitasnya.

Dari hasil analisis reliabilitas variabel X didapat nilai Alpha sebesar 0.792, Sedangkan hasil analisis reliabilitas variabel Y didapatkan nilai Alpha sebesar 0.553, Adapun nilai $r$ kritis (uji 2 sisi) pada signifikansi 5\% adalah sebesar $=0,374$. Dan dapat disimpulkan bahwa butir-butir instrument variabel $X$ dan variabel $Y$ dikatakan reliable.

Hal ini berarti bahwa penggunaan metode dalam pembelajaran akan lebih mudah bagi siswa dalam memahami materi dan siswa dapat mempraktikkan dalam keterampilan berbicara. Talking stick dapat digunakan di semua mata pelajaran. Di mana dalam kegiatan berbicara, setiap anggota kelompok memiliki kesempatan untuk memberikan kontribusi mereka dalam mendengarkan pandangan dan pemikiran anggota lain. ${ }^{15}$

\section{Hasil keterampilan berbicara siswa kelas VIII A MTs Al-Amien Putri 1 dengan menggunakan metode Talking Stick}

Berdasarkan permasalahan yang peneliti temukan bahwa siswa kelas VIII A MTs. Al-Amien Putri 1 merasa kesulitan dalam memahami materi dan menguasai kosa kata bahasa Arab yang disampaikan oleh guru serta siswa kurang mampu dalam berkomunikasi dengan menggunakan bahasa Arab. Untuk mencapai hasil keterampilan berbicara yang baik guru memilih metode baru bagaimana caranya siswa dapat mempraktikkan dan berbicara bahasa Arab dengan baik dalam kegiatan pembelajaran.

15 Anita Lie, Cooperative Learning (Jakarta: Grasindo, 2010), 61. 
Dengan itu, guru memilih menggunakan metode permainan yaitu dengan menggunakan metode Talking Stick.

Hasil penelitian menujukkan bahwa pada tabel model summary di atas didapatkan nilai $\mathrm{R}$ (Korelasi) 0,437 artinya pengaruh variabel independen (Metode Talking Stick) terhadap variabel dependen (Keterampilan Berbicara) adalah 437\%. Dan nilai R Square sebesar 19,1\%. Sedangkan pada tabel Anova pada kolom sig. terdapat nilai sig. sebesar 0,010 dibawah 0,05, maka dapat disimpulkan bahwa metode talking stick berpengaruh terhadap keterampilan berbicara siswa. Dan pada table ini juga membandingkan F-Hitung dan F-Tabel, dimana nilai F hitung sebesar 7.548 lebih besar dari pada F-Tabel sebesar 0,339.

\section{Pengaruh Penggunaan Metode Talking Stick terhadap Keterampilan Berbicara Siswa dalam Pembelajaran Bahasa Arab Kelas VIII MTs Al-Amien Putri 1}

Setelah mengetahui besarnya koefisien regresi, maka perlu dilakukan pengujian hipotesis untuk mengetahui apakah terdapat pengaruh atau tidak. Berdasarkan hasil uji regresi di atas, nilai signifikansinya sebesar 0.010. Karena nilai signifikansi lebih kecil dari 0,05 dan thitung $2.747>\mathrm{t}$ tabel 2.039. Artinya bahwa penggunaan metode talking stick berpengaruh terhadap keterampilan berbicara siswa dengan nilai sebesar 19,1\%, sedangkan $80,9 \%$ dipengaruhi oleh faktor lain.

Hal tersebut sesuai dengan pendapatnya Sumarsono yang menyebutkan bahwa metode pembelajaran kooperatif model Talking Stick mampu mendorong siswa untuk terlibat dalam proses pembelajaran secara aktif. ${ }^{16}$ Dalam hal ini aktivitas siswa ditunjukkan dengan aktifnya siswa dalam berbicara dengan menggunakan bahasa Arab. Aini dalam Suhardina juga menegaskan bahwa model Talking Stick memiliki kelebihan tersendiri, yaitu dapat menarik perhatian siswa, sehingga siswa bisa belajar lebih serius. ${ }^{17}$

16 Sumarsono, "Upaya Meningkatkan Prestasi Belajar Mata Pelajaran IPS Dengan Model Pembelajaran Kooperatif Tipe Talking Stick Konsep 'Menceritakan Lingkungan Alam Dan Buatan Di Sekitar Rumah Dan Sekolah' Terhadap Siswa Kelas III Semester I SD Negeri Wonorejo Kecamatan P," Jurnal Pendidikan Konvergensi (2019): 152.

17 I Putu Andre Suhardina, “Model Pembelajaran Talking Stick Sebagai Pendukung Penguasaan English Vocabulary Pada Anak Usia Dini," Pratama Widya 3, no. 1 (2018): 51. 


\section{Penutup}

Berdasarkan hasil penelitian serta pembahasan sebagaimana di atas, maka peneliti dapat mengambil sebuah kesimpulan dari penelitian bahwa Metode Talking Stick berpengaruh terhadap keterampilan berbicara siswa dalam pembelajaran bahasa Arab Kelas VIII MTs Al-Amien Putri 1. Hal ini terbukti pertama dengan nilai tabel anova pada kolom sig. tertera sebesar 0,010 dibawah 0,05. Kedua dengan membandingkan nilai F-Hitung dengan nilai F-Tabel, dimana nilai F hitung sebesar 7,548 lebih besar dari pada nilai F-Tabel sebesar 0, 339. Besar Metode Talking Stick untuk meningkatkan keterampilan berbicara siswa dalam pembelajaran bahasa Arab Kelas VIII MTs AlAmien Putri 1 adalah sebesar 0,191 yang artinya 19,1\%. Hal ini terlihat dari nilai $\mathrm{R}$ Square pada tabel Model Summary di kolom Standard Error of The Estimate, sementara $80,9 \%$ sisanya dipengaruhi oleh beberapa faktor lain.

\section{Daftar Pustaka}

Bandur, Agustinus. Penelitian Kualitatif: Metodologi, Desain Dan Teknik Analisis Data Dengan NVIVO 11 Plus. Jakarta: Mitra Wacana Media, 2016.

Efendy, Ahmad Fuad. Metodologi Pengajaran Bahasa Arab. Malang: Misykat, 2009.

Fajriah, Zahrotun. "Peningkatan Penguasaan Kosakata Bahasa Arab Melalui Penggunaan Media Kartu Kata Bergambar." Jurnal Pendidikan Usia Dini 09, no. 1 (2015).

Fathurrohman. "Model Talking Stick Dan Kemampuan Berbicara." Scholastica: Jurnal Pendidikan dan Kebudayaan 1, no. November (2019): 213-224.

Hermawan, Acep. Metodologi Pembelajaran Bahasa Arab. Bandung: PT Remaja Rosdakarya, 2011.

Lie, Anita. Cooperative Learning. Jakarta: Grasindo, 2010.

Marni, and M. Yusuf. T. "Penggunaan Metode Talking Stick Untuk Meningkatkan Mahârat Al-Kalâm Dalam Mata Pelajaran Bahasa Arab." Auladuna 2, no. 1 (2015): 87-103.

Mukrima, Syifa S. 53 Metode Belajar Dan Pembelajaran Plus Aplikasinya. Bandung: Bumi Siliwangi, 2014.

Mustofa, Syaiful. Strategi Pembelajaran Bahasa Arab Inovatif. Malang: UIN Maliki Press, 
2017.

Nawawi, Dkk. Keterampilan Berbicara Sebagai Suatu Keterampilan Berbahasa. Jakarta: Uhamka Press, 2017.

Rahmi, Alfi et al. "Penerapan Model Pembelajaran Kooperatif Tipe Talking Stick Dapat Meningkatkan Hasil Belajar IPS Siswa Kelas VB SDIT Insan Utama Pekanbaru." Jurnal Tunjuk AJar 1 (2018): 94-103.

Rusli, Mohammad \& Hisyam El Qadirie. Metode Penelitian Kuantitatif Dan Kualitatif. Sumenep: LP3M Pramadani, 2013.

Suhardina, I Putu Andre. “Model Pembelajaran Talking Stick Sebagai Pendukung Penguasaan English Vocabulary Pada Anak Usia Dini." Pratama Widya 3, no. 1 (2018).

Sumarsono. “Upaya Meningkatkan Prestasi Belajar Mata Pelajaran IPS Dengan Model Pembelajaran Kooperatif Tipe Talking Stick Konsep 'Menceritakan Lingkungan Alam Dan Buatan Di Sekitar Rumah Dan Sekolah' Terhadap Siswa Kelas III Semester I SD Negeri Wonorejo Kecamatan P." Jurnal Pendidikan Konvergensi (2019): 139-153.

Suprijono, Agus. Cooperative Learning Dan Aplikasi PAIKEM. Yogyakarta: Pustaka Belajar, 2009.

Taufik, Taufik. Pembelajaran Bahasa Arab MI. Surabaya: UIN Sunan Ampel Press, 2016. 